\title{
Measuring Positive Youth Development in Slovenia with a Focus on Gender and School-Level Differences
}

\section{Tina Pivec}

Educational Research Institute, Ljubljana, Slovenia

\section{Abstract}

The Positive Youth Development (PYD) approach postulates that all young people possess strengths (internal assets) that, when combined with resources in their environment (external assets), can impact the extent to which they thrive as they develop during their whole lifespan. Moreover, if both types (internal and external) of these assets are present, positive youth development is shown by the presence of the ${ }_{5} \mathrm{Cs}$ : competence, confidence, caring, connection and character. Since the PYD approach originates from and is well researched in the USA, all of the related measures were developed in that context. To determine whether the PYD model can be transferred for use in the Slovenian context, reliable and valid measures are foremost needed since some indicators of PYD might vary due to cultural and societal differences. The aim of this paper is to present the psychometric properties (reliability, validity) of PYD measures (i.e. internal, external assets, and the ${ }_{5} \mathrm{Cs}$ of PYD) in Slovenia and to determine gender and school-level differences. We used the Developmental Assets Profile (Scales, 2011) and the short version of the Positive Youth Development Questionnaire (Geldhof et al., 2014b). Our sample consisted of 1,979 students (57.4\% female; $M_{\text {age }}=15.43$ ) from lower and upper secondary schools in Slovenia. The results reveal that PYD can be partly transferred for use in the Slovenian context and that gender differences in particular exist in PYD. Implications for practice and guidelines for future research are discussed. 
Keywords: Positive youth development, developmental assets, the ${ }_{5} \mathrm{Cs}$, school level, gender

\section{Merjenje pozitivnega razvoja mladih v Sloveniji s poudarkom na razlikah v spolu in ravni} izobraževanja

Povzetek

Pozitivni razvoj mladih predvideva, da imajo vsi mladi svoje potenciale (notranji viri), ki lahko v kombinaciji z viri v njihovem okolju (zunanji viri) vplivajo na njihove uspehe skozi celotno življenje. Če so viri (tako notranji kot zunanji) prisotni, se pozitiven razvoj mladih kaže v prisotnosti kompetentnosti, samozavesti, karakterja, skrbi in povezanosti (t. i. $5 \mathrm{C}$-jev). Pozitivni razvoj mladih izvira iz ZDA in je tam dobro raziskan, saj so bile vse mere razvite $v$ tem kontekstu. Da bi lahko ugotovili, ali je model PYD prenosljiv v slovenski kontekst, moramo najprej imeti zanesljive in veljavne mere, saj se lahko nekateri kazalniki pozitivnega razvoja mladih razlikujejo zaradi kulturnih in družbenih razlik. Cilj tega prispevka je predstaviti psihometrične lastnosti (zanesljivost, veljavnost) vprašalnikov pozitivnega razvoja mladih (tj. notranji, zunanji viri ter $5 \mathrm{C}$-jev) v Sloveniji ter določiti razlike med spolom in šolskim kontekstom. Uporabljena sta bila Profil razvojnih virov (Scales, 2011) in kratka različica vprašalnika o pozitivnem razvoju mladih (Geldhof et al., 2014b). Naš vzorec je sestavljalo 1979 učencev $\left(57,4 \%\right.$ deklet; $\left.M_{\text {starost }}=15,43\right)$ iz zadnjih razredov osnovnih šol ter prvih treh letnikov srednjih šol. Rezultati so pokazali, da je paradigmo pozitivni razvoj mladih mogoče delno prenesti v slovenski kontekst in da pri pozitivnem razvoju mladih obstajajo zlasti razlike med spoloma. Predstavljeni so predlogi za pedagoško prakso in smernice za prihodnje raziskave.

Ključne besede: pozitivni razvoj mladih, razvojni viri, 5 C-jev, raven izobraževanja, spol

\section{Introduction}

Over the last few decades, the way researchers have viewed adolescents has shifted, not simply as troublesome and sensation-seeking people but also as individuals with numerous resources and advantages, which can be supported by developing various prevention and intervention programmes throughout their entire adolescence. One paradigm that arose in response to the shift in the understanding of adolescents is Positive Youth Development (PYD; Lerner et al., 2005). PYD emphasises the importance of support and seeks to reduce behavioural problems while striving 
to promote the competencies held by young people. Moreover, it describes youth development as the interaction of characteristics of adolescents and characteristics of their environment. Adolescent development is expected to be positive if their strengths (internal assets) are aligned with resources from their environment (external assets). If that is the case, this is likely to be reflected in indicators of PYD (i.e. the ${ }_{5} \mathrm{Cs}$ ) as well as not engaging in risky behaviour. Prosocial behaviour or an adolescent contribution to society are expected to be more strongly present (Lerner et al., 2005). This paradigm has been empirically tested primarily in the United States (e.g. Benson et al., 2011; Lerner et al., 2005), while in Europe it has only come to the forefront of research in the last decade (e.g. Beck \& Wiium, 2019). In Slovenia, the model has yet to be fully tested, although individual connections between positive youth development and different phenomena have been confirmed, e.g. academic achievement (Kozina et al., 2019) and risky behaviours (Pivec et al., 2020).

Since only particular connections were examined in the Slovenian context, the rationale of this paper is to see whether the PYD model is transferable for use in that setting. To test this, we first required reliable and valid measures because some indicators of PYD may vary due to cultural and societal differences. Therefore, this paper aims to present the psychometric properties (reliability, structural validity) of PYD measures (i.e. internal, external assets, and the ${ }_{5}$ Cs of PYD) in Slovenia. Second, we look at possible gender and age differences with a focus on differences on the school level (i.e. lower secondary schools vs. upper secondary schools).

\section{The Positive Youth Development Perspective}

The PYD perspective is based on the Relational-developmental-systems paradigm (Overton, 2015), which concentrates on the important interplay of individual characteristics and contexts (e.g. school, family, community, society) where it especially stresses the importance of seeing adolescents as active agents of their society. Further, PYD is a strengths-based model, which highlights the plasticity of individual development and mutual individual $\leftrightarrow$ context relationships. Through this lens, PYD focuses on enhancing young people's strengths that they themselves or other members from different contexts appreciate (i.e. family, peers, teachers, neighbours) (Lerner et al., 2019). The two most prominent models advocating youth positive development are Developmental Assets (DA; Benson, 2003) and the 5Cs of PYD (Lerner et al., 2005). 
DA are divided into external assets and internal assets. External assets are defined as support (i.e. family support, positive family relationships, other relationships with adults, a caring neighbourhood, a good school climate, parental involvement in schooling), empowerment (i.e. community values, helping others), boundaries and expectations (i.e. family boundaries, boundaries within the school, boundaries within neighbourhoods, adult role models, positive peer influence, high expectations) and constructive use of time (i.e. creative activities, youth programmes, religious activities, time spent at home). Internal assets include a commitment to learning (i.e. motivation to succeed, learning commitment, regular completion of homework, connection to the school, reading for pleasure), positive values (i.e. care, equality and social justice, integrity, honesty, responsibility, self-control), social competencies (i.e. planning and decision-making, interpersonal competencies, cultural competencies, appropriate conflict resolution) and a positive identity (i.e. self-esteem, positive opinion about one's future) (Benson et al., 2011).

The ${ }_{5} \mathrm{Cs}$ include competence, confidence, character, connection and caring (Bowers et al., 2010). Competence is a positive opinion about one's actions in specific areas (e.g. social competencies and academic achievement), while confidence is defined as an inner feeling of positive self-esteem and self-efficacy. Character is viewed as the possession of ethical standards that are consistent with social and cultural norms. Connection represents the intertwining of positive mutual relations of the individual with his or her important others, institutions and communities. Caring combines empathy and sympathy.

Both frameworks were well established in the past, where especially the ${ }_{5} \mathrm{Cs}$ were recognised as the most empirically supported framework to date (Heck \& Subramaniam, 2009). The two paradigms were first established and based on the theory and previous findings (i.e. Leffert et al., 1998; Lerner et al., 2005) and then specific questionnaires were created or adjusted to measure either DA or the ${ }_{5} \mathrm{Cs}$ (Geldhof et al., 2014b; Syvertsen et al., 2019). The Search Institute formulated a questionnaire to assess young people's experiences and beliefs regarding 40 assets (i.e. the Profiles of Student Life: Attitudes and Behaviors Survey; Leffert et al., 1998). They were first meant to serve as the basis for conversation and action and not as a measurement instrument (Syvertsen et al., 2019). However, later, expected connections with several positive outcomes (i.e. positive academic, social, emotional and behavioural outcomes) were confirmed (Benson et al., 2011) and 
additional analyses were performed to examine the scales' reliability and validity (Scales, 2011). Recently, Syvertsen and colleagues (2019) undertook a theoretical and empirical examination of DA which in turn led to certain changes to the mentioned questionnaire (i.e. they removed some items or moved them to a different asset). In the last decade, another DA questionnaire has emerged for use in emergency settings (i.e. the 13-item Em-DAP; Scales et al., 2015). In the European context, it is hard to find studies that relied on the Developmental Assets Profile, which is used in the present study, even though a recent study conducted in Spain revealed the good factorial validity of the external and internal assets (Gomez-Baya et al., 2021).

Measurement invariance was considered for DA regarding grade and gender identity in the USA (Syvertsen et al., 2019). Configural, metric and scalar invariance were established for Positive identity, Positive values and a newly invented asset category called Mattering and belonging across grade. Further, configural and metric invariances were shown for Social competencies, Support, and Boundaries (a newly invented asset), and partial metric invariance was established for Academic engagement (a newly invented construct that includes Commitment to learning). Moreover, at least partial scalar invariances were established for gender identity for Positive values, Support, Mattering and Belonging (a newly developed construct in this study), Boundaries, Positive identity, and Social competencies. The metric invariance of Constructive use of time for gender identity was not examined since the mentioned authors removed this asset as it was examined as a collection of various extracurricular activities. Regardless, more research is needed in this area.

Alternatively, the measurement properties of the $5 \mathrm{Cs}$ model have been more thoroughly examined in the US context (e.g. Geldhof et al., 2014a). The first measure of the $5 \mathrm{Cs}$ consisted of over 80 items and was understood as a higher-order measure of PYD that comprised 5 first-order latent constructs (i.e. confidence, competence, character, caring, connection) (Lerner et al., 2005). The ${ }_{5} \mathrm{Cs}$ were found to be a robust construct throughout early adolescence while scales differed for middle adolescents (Bowers et al., 2010). Later, the scale was shortened to 34 items (see Geldhof et al., 2014b) and applies to young people aged 10 to 18 years. The analyses suggested that a model without a higher-order PYD construct fitted the data worse than a model with 5 first-order latent constructs. Moreover, the bifactor model had the most appropriate fit, in which each item represents a lower-order construct and a more general construct. All the aforementioned studies 
were conducted in the US context. Recently, the psychometric properties of the ${ }_{5} \mathrm{Cs}$ were examined in European countries. In Ireland (Conway et al., 2015) and Spain (Gomez-Baya et al., 2021), a five-factor model provided a good fit to the data while in Norway (Årdal et al., 2018) the Cs were separated into two constructs: the efficacious Cs (consisting of competence, confidence, connection) and socio-emotional Cs (comprising caring and character). It is important to note that only in Spain has the short version of the PYD questionnaire (Geldhof et al., 2014b) been applied, suggesting that more research is needed to determine whether the questionnaire is applicable in Europe.

Measurement invariance testing was considered for the ${ }_{5} \mathrm{Cs}$ in several studies, although no study included the short version of the PYD questionnaire (Geldhof et al., 2014b). In a European context but with a previous version of the PYD questionnaire (Lerner et al., 2005), Conway and colleagues (2015) examined measurement invariance for gender and age (early vs. late adolescence). They established partial scalar invariance for gender and scalar invariance for age.

\section{Gender and school-level differences}

PYD can serve as a useful framework for designing prevention and intervention programmes. To be able to do that, more needs to be known about possible differences between individuals and different contexts. Therefore, gender and school-level differences will be examined in this study to ensure that PYD principles are distributed properly. Still, current international gender, age or school-level comparisons regarding DA or the ${ }_{5} \mathrm{Cs}$ are limited.

Existing studies of DA (Gomez-Baya et al., 2021; Leffert et al., 1998; Soares et al., 2019) reveal some gender differences in either 4 internal and 4 external assets or 40 DA overall. Gomez-Baya and colleagues (2021) show that females reported higher support, empowerment, boundaries and expectations, commitment to learning, positive values, and social competencies while males reported a higher positive identity. There were no differences in constructive use of time. Even less is known about age or school-level differences in DA. Soares and colleagues (2019) confirmed that certain age and grade-related differences exist. The lower the school grade, the higher overall DA that were reported, while another study suggested that DA tended to decrease during lower secondary school and stabilised during upper secondary school (Leffert et al., 1998). 
Even though one may find a considerable number of studies focused on gender, age or grade differences across the ${ }_{5} \mathrm{Cs}$, this topic still entails a research gap. Regarding gender differences in the $5 \mathrm{Cs}$, females were found to report higher overall PYD scores than males (Phelps et al., 2009). Moreover, specific differences across the ${ }_{5} \mathrm{Cs}$ were observed, such as that females reported more connection, character and caring, while males presented higher scores for confidence (Årdal et al., 2018; Conway et al., 2015). Gomez-Baya and colleagues (2019) found that males reported higher competence as well. As for age or grade differences in the ${ }_{5} \mathrm{Cs}$, some ambiguous patterns were observed. For instance, Gomez-Baya et al. (2019) did not detect any age differences across the $5 \mathrm{Cs}$, whereas Conway et al. (2015) reported that younger adolescents (aged 11 to 15 years) showed higher caring, character and connection than older adolescents (aged 16 to 18 years). No differences were found for confidence and competence.

\section{The Slovenian context}

Slovenia is a small (population: 2.1 million) and newly-formed country (in existence for 30 years) located in Southern Central Europe, bordering Italy, Croatia, Austria and Hungary. In Slovenia, primary education is arranged as a single-structure (ISCED1 and ISCED2) 9-year compulsory school attended by students aged from 6 to 15 years. Upper secondary education (ISCED 3 ) consists of 2- to 5-year non-compulsory school for students who have completed compulsory basic education, typically at the age of 15. Upper secondary education is divided into general education that includes 4-year gymnasium programmes, 4-year upper secondary technical education, 3-year upper secondary vocational education (with a possibility of continuing for 2 years in vocational/technical education programmes), and 2-year short, upper secondary vocational education (Taštanoska, 2017). In the 2020/2021 school year, 193,158 students were attending primary education and 73,854 students upper secondary education in Slovenia (SURS, 2021).

In Slovenia, mental health statistics reveal disturbing trends of high suicide rates in the general population (e.g. a suicide rate of 20 per 100,000 in the last decade; Roškar et al., 2020) and among Slovenian youth (above the European average; Jeriček Klanšček et al., 2018). Further, HBSC findings show that Slovenian students are more stressed because of school than their peers in other countries (Jeriček Klanšček et al., 2018). In fact, older adolescents (15-19 years) compared to younger adolescents (6-14 years) and 
in girls compared to boys (Jeriček Klanšček et al., 2018) reported an increase in anxiety disorders from 2008 to 2014. While the majority of adolescents are satisfied with their lives (Jeriček Klanšček et al., 2018), these alarming trends call for additional support and research in the area of youth development. One possible systemic solution may be the PYD perspective and its tailored interventions.

\section{The present study}

PYD is a well-researched paradigm, albeit mostly in the USA. Therefore, the first aim of this study is to consider whether PYD can be extended for use in the Slovenian context. Since studies examining the psychometric properties of the Developmental Assets Profile and the short version of the PYD questionnaire are lacking, we consider the reliability and structural validity of both questionnaires in the Slovenian context. We hypothesise that the data will indicate a good fit for the two questionnaires because both have been proven to be psychometrically sound measures in the European context (Conway et al., 2015; Gomez-Baya et al., 2021). We hypothesise that the bifactor model of the $5 \mathrm{Cs}$ will have a better fit than a model containing 5 first-order factors. Further, we hypothesise that metric invariance will be (at least partly) established for gender and school level. The second aim of this paper is to examine differences in the assets and ${ }_{5} \mathrm{Cs}$ across gender and school level (lower secondary schools vs. upper secondary schools). It is particularly important to consider possible gender and school-level differences to be able to efficiently tailor interventions according to students' needs as it is crucial that, before planning interventions, researchers gain as much information as possible to fully contextualise the interventions (Roth \& Brooks-Gunn, 2016). Thus, an in-depth examination of gender and school-level differences may provide additional information on how developmental assets and the $5 \mathrm{Cs}$ are distributed in each group and contribute to effective interventions. In line with previous studies (e.g. Årdal et al., 2018; Gomez-Baya et al., 2019; Gomez-Baya et al., 2021; Soares et al., 2019), we hypothesise that some gender and school-type differences will be detected in DA and the ${ }_{5} \mathrm{Cs}$. More precisely, females will score higher for support, empowerment, boundaries and expectations, commitment to learning, positive values, and social competencies. Students from lower secondary schools will have more DA than students from upper secondary schools. As for the ${ }_{5} \mathrm{Cs}$, females will report higher scores for connection, character and caring than males, who will report greater confidence 
and competence. Students from lower secondary school will report higher scores for caring, character and connection than upper secondary students. Moreover, the data were collected during the COVID-19 pandemic and thus this situation will also be partly considered in the discussion.

\section{Method}

\section{Participants}

The sample included 1,979 participants from Slovenia (57.4\% female, 42.5\% male, o.1\% non-binary), aged from 13 to $19(M=15.34 ; S D=1.19)$. The majority of participants were attending 20 different upper secondary schools $(1,404$ students; $70.8 \%)$; most being female (57.8\%). The age of these students varied from 14 to $19(M=15.91 ; S D=0.91)$. The other third of the participants were attending 21 different lower secondary schools (577 students; $29.7 \%)$ and were aged between 13 and 16 years $(M=13.96$; $S D=0.38)$. Most of them were female (56.3\%).

\section{Measures}

Developmental assets. The Developmental Assets Profile (Benson, 2003) was used to measure DA. It comprises 62 items evaluating young people's experience of DA. They are divided into internal and external asset categories. External assets refer to the family, peers, school and society. They include Support (e.g. "I have a family that gives me love and support"), Empowerment (e.g. "I feel valued and appreciated by others"), Boundaries and expectations (e.g. "I have friends who set good examples for me"), and Constructive Use of Time (e.g. "I am involved in creative things such as music, theatre or other arts"). Internal assets concern the individual and consist of Commitment to Learning (e.g. "I enjoy learning"), Positive values (e.g. "I tell other people what I believe in"), Social Competencies (e.g. "I accept people who are different from me") and a Positive Identity (e.g. "I am sensitive to the needs and feelings of others"). The participants expressed to what extent as certain item referred to themselves or their relationships with family, friends and other people in their contexts on a 4-point scale $(1=$ Not at all or rarely, $4=$ Extremely or almost always). The original reliabilities for each construct were as follows: .80 for Support, .74 for Empowerment, .84 for Boundaries and expectations, .56 for Constructive use of time, .83 for Commitment to learning, .85 for Positive values, .79 for 
Social competencies and .79 for Positive identity (Search Institute, 2005). The scales' reliabilities are presented in the Results section.

The 5 Cs. The short form of the PYD questionnaire (Geldhof et al., 2014b) was used to measure the 5 Cs (i.e. Competence, Confidence, Character, Caring, Connection). It contains 34 items with responses according to a 5-point Likert scale (ranging from $1=$ strongly disagree to 5 = strongly agree, for example). Sample items that measure the ${ }_{5} \mathrm{Cs}$ are Competence (e.g. "I do very well in my classwork at school"); Confidence (e.g. "All in all, I am glad I am me"); Character (e.g. "I hardly ever do things I know I shouldn't do"); Connection (e.g. "My friends care about me"); and Caring (e.g. "When I see another person who is hurt or upset, I feel sorry for them"). The original reliabilities of the constructs were as follows: .73.76 for Competence, $.75-.82$ for Confidence, $.78-.82$ for Character, $.87-.90$ for Caring, and .79-.83 for Connection (Geldhof et al., 2014b). The scales' reliabilities for the sample considered are presented in the Results section.

\section{Procedure}

The data were collected during the first wave of the following research project, which aims to investigate longitudinal pathways for positive youth development: Positive Youth Development in Slovenia: Developmental Pathways in the Context of Migration. Before the data collection began, the research was approved by the Committee for Ethical Research at the Faculty of Arts of the University of Maribor and sampling was applied (all high school types were included according to the proportion of students that attend each type). All lower and upper secondary schools in Slovenia were then divided into two groups according to the number of additional hours of Slovenian language being offered to migrant students. Lower and upper secondary schools with the highest number of additional hours of Slovenian language for migrant students were invited to participate in the study. In the meantime, another group of lower and upper secondary schools that did not have any additional hours of Slovenian language for migrant students was randomly sampled and invited to participate in the study. When schools agreed to participate, additional sampling of the classes of upper secondary schools was performed. We randomly assigned the two classes per year that were to participate in the study. All classes from each participating lower secondary school were included in the study. After obtaining informed consent from their parents, the students responded either online or on paper due to the COVID-19 situation. The time was not 
limited, and they were supervised by the school coordinator (teacher or school counsellor) who answered any questions if they had them.

\section{Data analysis}

After examining descriptive statistics, correlations and reliabilities using IBM SPSS Statistics 27, we considered the ESEM (Exploratory Structural Equation Modelling) model of DA and the CFA model of the ${ }_{5} \mathrm{Cs}$ using Mplus (Version 8.6; Muthén \& Muthén, 1998-2021) to examine the proposed models' structural validity. The full information maximum likelihood (FIML) algorithm was used to handle missing data and assess parameters in the model. Separate ESEM or CFA was conducted for each construct. If indicated by modification indices and justified by the content of the items, correlated errors were allowed between these items. ESEM was carried out for DA and CFA for the ${ }_{5}$ Cs. We applied ESEM to DA since the construct can be organised in two different ways (i.e. internal and external assets or as asset contexts: personal (self), social, family, school and community; Scales, 2011). This means that the DA factors are intercorrelated and thus ESEM can provide a better solution since it allows the pre-specification of target and non-target loadings, while all non-target loadings are close to o and are not fixed at o like with the CFA (Morin et al., 2015). The two possible solutions for DA (internal and external assets and asset contexts) will be included in the analysis to compare both models. In the initial CFA for the $5 \mathrm{Cs}, 14$ pairs of the same-facet items were allowed to correlate (see Tirrell et al., 2019). Item loadings were interpreted according to Tabachnick and Fidell (2006), who suggested cut-off values ranging from 0.32 (poor), 0.45 (fair), 0.55 (good), 0.63 (very good) to 0.71 (excellent). Model fit was assessed with chi-squares, comparative fit indices (CFI), root-meansquare error of approximation (RMSEA), and standardised root-meansquare residual (SRMR), following recommendations by $\mathrm{Hu}$ and Bentler (1999) for a good fit: CFI $>.95$, RMSEA $<.06$ and the SRMR $<.08$. For an adequate fit, the following cut-off values were applied: CFI > .90, RMSEA < .08 and the SRMR < .08 (Hair et al., 1998).

After considering the psychometric properties of the two PYD measures, Multigroup Confirmatory Factor Analysis (MGCFA) was applied using Mplus (version 8.6; Muthén \& Muthén, 1998-2021) to estimate measurement invariance by gender and school level (i.e. construct, metric and scalar invariance) for each developmental asset and C of PYD separately. The series of multi-group models was compared to assess if the same 
constructs were examined in each group. If partial measurement invariance was not achieved, some constraints were removed. A change in CFI (equal to or less than .01) was used as an indicator of measurement invariance since chi-square difference tests depend on the sample size (Cheung \& Rensvold, 2002).

Finally, MANOVAs with a Bonferroni correction were used to compare groups or levels across gender and school. MANOVA was applied instead of univariate ANOVAs to avoid Type I error since only one instead of several tests are being conducted, meaning that MANOVA takes account of the relationship between the combinations of dependent variables, which is not possible in the case of a series of univariate ANOVAs, and MANOVA holds greater power for detecting an effect. Since only two participants defined themselves as non-binary, they were excluded from further gender analysis.

\section{Results}

After the descriptive statistics, the reliability analyses are outlined. The results of CFA and ESEM for each PYD measure together with measurement invariance across gender and school are then presented. At the end, differences across gender and school are described.

\section{Descriptive statistics}

Descriptive statistics and correlations for the whole sample are presented to provide an insight into the data (see Table 1 ). The great majority of the variables are positively correlated, except for Confidence and Caring, which are not correlated with each other at all.

\section{Exploratory Structural Equation Model (ESEM) and Confirmatory Factor Analysis (CFA)}

In this section, ESEM results for the DA and CFA results for the ${ }_{5} \mathrm{Cs}$ are presented.

The ESEM results showed an adequate fit for DA with 8 latent constructs (Support, Empowerment, Boundaries and expectations, Constructive use of time, Commitment to learning, Positive values, Social competencies, Positive identity): $\chi^{2}(1420)=4701.37, p<$. 001, CFI $=.922$, RMSEA = $.034,90 \%$ CI $[.033, .035]$, SRMR $=.023$. For Support, the majority of target loadings were fair $(p s<.001)$, except for items that refer to support from 
Table 1. Descriptive statistics and correlations of the whole sample.

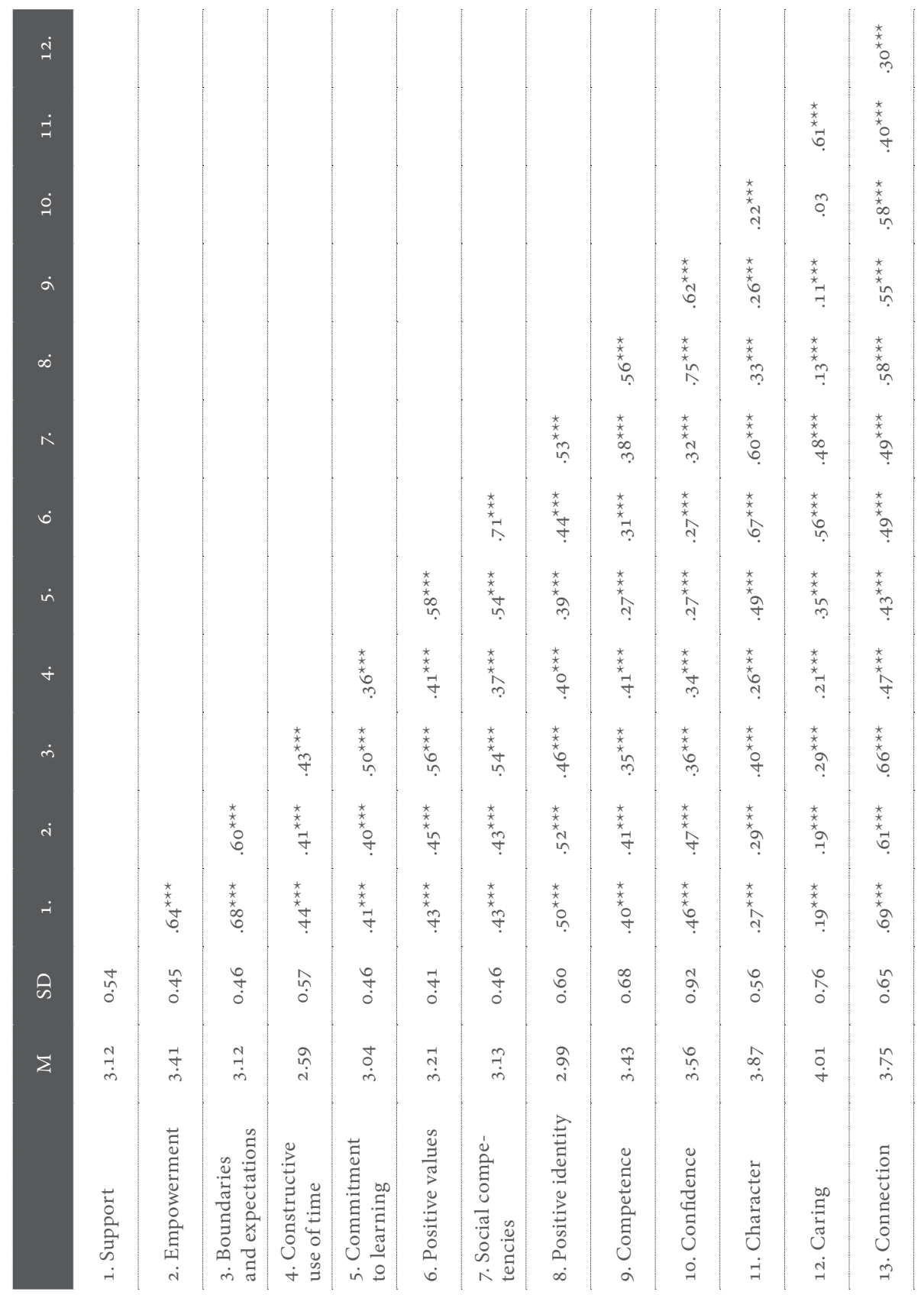

Notes. ${ }^{*} p<.05 .{ }^{* *} p<.01 .{ }^{* *} p<.001$ 
other adults and neighbours. Almost all non-target loadings were poor. For Empowerment, almost all target loadings were almost fair (all exceeded .38; ps <.oo1), except for items that relate to self-perception and family decisions. Almost all non-target loadings were poor, except for two items that refer to school rules. The most troublesome of the DA latent constructs are Boundaries and expectations and Constructive use of time. Only two target loadings of items of Boundaries and expectations were almost fair ( $p s<$ .001). The other 6 Boundaries and expectations items' target loadings were poor. Non-target loadings varied between .01 and .82 .

As for Constructive use of time, all of the target loadings were poor (below .21), indicating that both Constructive use of time and Boundaries and expectations are problematic constructs and should be probed into. For Commitment to learning, target loadings for 4 out of 7 items were higher than .36 ( $p s<.001)$. Almost all non-target loadings were poor. Only 6 out of 13 target loadings of Positive values were fair $(p s<.001$ ), indicating Positive values may be a problematic construct. Almost all non-target loadings were poor. Moreover, Social competencies appear to be questionable as well since only two target loadings were almost fair (higher than .42; $p$ s < .oo1). Almost all non-target factor loadings were poor. As for Positive identity, almost all target loadings were higher than .52 ( $p s<.001)$ while only one item's target loading was poor $(p<.05)$. All non-target loadings were poor.

The following correlated errors were included in the model. They were based on modification indices when they could be justified by the content: item 15 with 21 for Boundaries and expectations (both relate to school rules), item 35 with 36 for Positive values (both refer to being responsible) and item 56 with 57 for Positive identity (both are connected with strategies to deal with difficult situations). We examined a second ESEM model, which contained factors that refer to different contexts (i.e. personal (self), social, family, school, community). Even after including 12 modification indices (as justified by the content), the model did not show an adequate fit: $\chi^{2}(1579)=6093.76, p<.001, \mathrm{CFI}=.905, \mathrm{RMSEA}=.038,90 \%$ CI $[.037, .039]$, $\mathrm{SRMR}=.031$. Target loadings for the Personal factor varied from -.10 to .68 ( $p$ s < .001) while non-target loadings were poor. Target loadings for Social assets were poor (ranging from .15 and .46 ; $p$ s $<.001$ ) and non-target loadings were also poor. As for Family assets, target loadings were from .24 to .61 ( $p$ s < .001) while non-target loadings were poor. Target loadings for School assets ranged from .07 to .67 ( $p s<.001)$ whereas non-target loadings 
were poor. Community assets' target loadings were poor (the majority of ps <.001) and non-target loadings were poor as well. The model fit and low target loadings of context-related assets indicated that the solution with 8 factors was better.

CFA results showed an adequate fit for the $5 \mathrm{Cs}$ with 5 latent constructs (Competence, Confidence, Character, Caring, Connection): $\chi^{2}(503)$ $=3368.97, p<.001, \mathrm{CFI}=.910, \mathrm{RMSEA}=.054,90 \%$ CI $[.052, .056]$, SRMR $=.063$. For Competence, all factor loadings were fair $(p s<.001)$. All factor loadings for Confidence were very good or even excellent $(p s<.001)$. For Character, almost all factor loadings were fair (they were above .38; $p$ s $<$.oo1), except for items referring to conduct behaviour. All factor loadings for Caring were good or very good ( $p$ s $<$.oo1). For Connection, all factor loadings were fair $(p s<.001)$. In the CFA for the ${ }_{5} \mathrm{Cs}$, the 14 pairs of the same-facet items (in Competence, Confidence, Character and Connection) were allowed to correlate. Moreover, we applied a bifactor model that allows for items to simultaneously indicate each first-order factor and a general construct (i.e. PYD). The bifactor model of the ${ }_{5} \mathrm{Cs}$ did not converge.

\section{Reliability analyses}

First, we examined the reliability of each scale for the whole sample. Since gender and school level are to be compared, we examined the internal consistencies for each group separately.

The Cronbach alphas of DA for the whole sample were adequate and varied from .70 to .82 , except for Constructive use of time, which was only .43. Similarly, the reliabilities of DA except for Constructive use of time (males: .42; females: .45) according to gender were adequate and ranged from .69 to .82 for males and from .67 to .82 for females. The reliabilities of DA according to school level were from .70 to .84 for lower secondary school and from .68 to .82 for upper secondary school, except for Constructive use of time (lower secondary school: .44; upper secondary school: .42).

The Cronbach alphas of the 5 Cs for the whole sample ranged from .73 to .92. The internal consistencies for gender were from .72 to .91 for males and from .70 to .92 for females. The reliabilities of the $5 \mathrm{Cs}$ according to the school level were adequate: for lower secondary schools, they varied from .76 to .92 and for upper secondary schools from .72 to 92 . 


\section{Measurement invariance}

Table 2 shows fit indexes of MGCFA of the DA. For gender, the configural invariance model indicated an adequate fit, meaning that similar patterns of observed and latent constructs across gender emerged. In the metric invariance model, in which factor loadings on latent variables were constrained to be equal across gender, the fit indices showed construct and metric equivalence across countries. In the scalar invariance model, in which variables were fixed to have the same intercept across gender, an adequate or good model fit was not achieved. Following the modification indices (means of items 33 and 31 were allowed to vary across gender), partial scalar invariance was attained. As for school level, the configural invariance model, metric invariance model and scalar invariance model indicated an adequate fit, meaning scalar invariance for school level of the DA was achieved.

Table 2. Measurement invariance models and goodness-of-fit indexes of multigroup analyses of developmental assets across gender and school types

\begin{tabular}{|c|c|c|c|c|}
\hline \multirow[t]{2}{*}{ Model } & \multicolumn{4}{|c|}{ Model fit indices } \\
\hline & $\chi^{2}(\mathrm{df})$ & RMSEA & 90\% CI RMSEA & CFI \\
\hline \multicolumn{5}{|l|}{ Gender } \\
\hline Configural invariance & $6333.25(2840)$ & .035 & $.034-.036$ & .915 \\
\hline Metric invariance & $7074.65(3272)$ & .034 & $.033-.035$ & .908 \\
\hline Scalar invariance & $7518.88(3326)$ & .036 & $.035-.037$ & .898 \\
\hline $\begin{array}{l}\text { Partial scalar } \\
\text { invariance }\end{array}$ & $7424.97(3324)$ & .035 & $.034-.036$ & .900 \\
\hline \multicolumn{5}{|l|}{ School type } \\
\hline Configural invariance & $6349.89(2840)$ & .035 & $.035-.036$ & .917 \\
\hline Metric invariance & $7077.40(3272)$ & .034 & $.033-.035$ & .910 \\
\hline Scalar invariance & $7289.87(3326)$ & .035 & $.034-.036$ & .906 \\
\hline
\end{tabular}

Notes. $\mathrm{X} 2=$ Chi-square; $\mathrm{df}=$ degrees of freedom; $\mathrm{CFI}$ - Comparative Fit Index; RMSEA = root mean square error of approximation; $\mathrm{Cl}=$ confidence interval

In Table 3, fit indexes of MGCFA of the ${ }_{5}$ Cs are presented. For gender, the configural invariance and metric invariance model indicated an adequate fit. In the scalar invariance model, in which variables were fixed to have the same intercept across gender, an adequate or good model fit was not achieved. Following the modification indices (means of item 33 were allowed to vary across gender and items 22 and 23 were allowed to correlate since it was justified by the content), partial scalar invariance was attained. 
Regarding school level, the configural, metric and scalar invariance models showed an adequate fit.

Table 3. Measurement invariance models and goodness-of-fit indexes of multigroup analyses of the $5 \mathrm{Cs}$ across gender and school types

\begin{tabular}{lcccc}
\multicolumn{1}{c}{ Model } & \multicolumn{4}{c}{ Model fit indices } \\
\hline & $\chi^{2}(\mathrm{df})$ & RMSEA & 90\% CI RMSEA & CFI \\
\hline Gender & & & $.052-.056$ & .907 \\
\hline Configural invariance & $3881.53(1006)$ & .054 & $.052-.056$ & .905 \\
\hline Metric invariance & $3989.11(1035)$ & .054 & $.055-.058$ & .893 \\
\hline Scalar invariance & $4398.45(1064)$ & .056 & $.051-.054$ & .907 \\
\hline $\begin{array}{l}\text { Partial scalar } \\
\text { invariance }\end{array}$ & $3939.14(1061)$ & .052 & & .908 \\
\hline School type & & & $.048-.051$ & .907 \\
\hline Configural invariance & $3406.22(1006)$ & .050 & $.047-.051$ & .903 \\
\hline Metric invariance & $3465.98(1035)$ & .049 & $.048-.051$ & \\
\hline Scalar invariance & $3583.70(1064)$ & .049 & & .048 \\
\hline
\end{tabular}

Notes. $\times 2=$ Chi-square; $d f=$ degrees of freedom; $C F I$ - Comparative Fit Index; RMSEA = root mean square error of approximation; $\mathrm{Cl}=$ confidence interval

\section{Differences in gender and school level}

In this section, differences in DA and the ${ }_{5} \mathrm{Cs}$ across gender and school type are presented. To examine these differences, MANOVA was employed.

Regarding gender, MANOVA revealed some significant differences among the constructs $\left(\Lambda=0.76 ; F=48.51 ; p<.001\right.$; partial $\left.\eta^{2}=0.24\right)$. Means and standard deviations are presented in Table 4. Pairwise comparisons with a Bonferroni adjustment for multiple comparisons (mean differences were significant at the .05 level) were applied to examine differences across gender. Males reported higher Support $(p<.001)$, Empowerment $(p<.05)$ and a Positive identity $(p<.001)$ whereas females reported higher Commitment to learning $(p<.001)$, Positive values $(p<.001)$ and Social competencies $(p<.001)$. There were no gender differences in Boundaries and expectations and Constructive use of time. As for the ${ }_{5} \mathrm{Cs}$, males reported higher Competence $(p<.001)$, higher Confidence $(p<.001)$ and a higher Connection $(p<.05)$ than females. On the other hand, females scored higher for Character $(p<.001)$ and Caring $(p<.001)$. 
Table 4. The 5 Cs by gender: MANOVA

\begin{tabular}{lccccc}
\multicolumn{1}{c}{ Variable } & $\begin{array}{c}\text { Lower } \\
\text { secondary } \\
\text { school } \\
M(S D)\end{array}$ & $\begin{array}{c}\text { Upper } \\
\text { secondary } \\
\text { school } \\
M(S D)\end{array}$ & $S S$ & $d f$ & $F$ \\
\hline Support & $3.18($ o.52) & $3.08(0.55)$ & 4.61 & 1 & $16.00^{* * *}$ \\
\hline Empowerment & $3.44(0.44)$ & $3.40(0.47)$ & 0.94 & 1 & $4.56^{*}$ \\
\hline Boundaries and expectations & $3.10(0.46)$ & $3.14(0.45)$ & 0.62 & 1 & 3.02 \\
\hline Constructive use of time & $2.58(0.55)$ & $2.59(0.58)$ & 0.01 & 1 & 0.02 \\
\hline Commitment to learning & $2.95(0.47)$ & $3.11(0.44)$ & 12.86 & 1 & $61.94^{* * *}$ \\
\hline Positive values & $3.13(0.44)$ & $3.27(0.38)$ & 9.18 & 1 & $55.16^{* * *}$ \\
\hline Social competencies & $3.06(0.47)$ & $3.18(0.44)$ & 7.38 & 1 & $35.54^{* * *}$ \\
\hline Positive identity & $3.14(0.55)$ & $2.88(0.61)$ & 33.10 & 1 & $95.73^{* * *}$ \\
\hline Competence & $3.62(0.65)$ & $3.29(0.66)$ & 51.06 & 1 & $119.17^{* * *}$ \\
\hline Confidence & $3.84(0.82)$ & $3.36(0.94)$ & 112.68 & 1 & $142.47^{* * *}$ \\
\hline Character & $3.74(0.59)$ & $3.96(0.51)$ & 24.60 & 1 & $83.12^{* * *}$ \\
\hline Caring & $3.74(0.79)$ & $4.22(0.67)$ & 108.58 & 1 & $205.43^{* * *}$ \\
\hline Connection & $3.79(0.65)$ & $3.73(0.64)$ & 2.09 & 1 & $4.98^{*}$
\end{tabular}

Notes. SS: Sum of Squares; ${ }^{*} p<.05 ;{ }^{* *} p<.01 ;{ }^{* * *} p<.001$

Table 5. The 5 Cs by school: MANOVA.

\begin{tabular}{lccccc}
\hline \multicolumn{1}{c}{ Variable } & $\begin{array}{c}\text { Lower } \\
\text { secondary } \\
\text { school } \\
M(S D)\end{array}$ & $\begin{array}{c}\text { Upper } \\
\text { secondary } \\
\text { school } \\
M(S D)\end{array}$ & $S S$ & $d f$ & $F$ \\
\hline Support & $3.17(0.52)$ & $3.10(0.55)$ & 2.16 & 1 & $7.44^{* *}$ \\
\hline Empowerment & $3.41(0.45)$ & $3.41(0.46)$ & 0.01 & 1 & 0.04 \\
\hline Boundaries and expectations & $3.13(0.46)$ & $3.12(0.45)$ & 0.02 & 1 & 0.09 \\
\hline Constructive use of time & $2.70(0.57)$ & $2.54(0.56)$ & 10.47 & 1 & $32.87^{* * *}$ \\
\hline Commitment to learning & $3.08(0.48)$ & $3.03(0.46)$ & 1.25 & 1 & $5.82^{*}$ \\
\hline Positive values & $3.23(0.44)$ & $3.20(0.41)$ & 0.27 & 1 & 1.56 \\
\hline Social competencies & $3.16(0.47)$ & $3.11(0.46)$ & 0.88 & 1 & $4.17^{*}$ \\
\hline Positive identity & $3.06(0.60)$ & $2.96(0.60)$ & 4.22 & 1 & $11.70^{* *}$ \\
\hline Competence & $3.54(0.71)$ & $3.39(0.66)$ & 9.44 & 1 & $20.86^{* * *}$ \\
\hline Confidence & $3.61(0.93)$ & $3.55(0.92)$ & 1.83 & 1 & 2.17 \\
\hline Character & $3.89(0.59)$ & $3.86(0.54)$ & 0.51 & 1 & 1.65 \\
\hline Caring & $4.02(0.79)$ & $4.01(0.75)$ & 0.01 & 1 & 0.01 \\
\hline Connection & $3.82(0.68)$ & $3.72(0.63)$ & 4.08 & 1 & $9.74^{* *}$ \\
\hline
\end{tabular}

Notes. SS: Sum of Squares; ${ }^{*} p<.05 ;{ }^{* *} p<.01{ }^{* * *} p<.001$

Regarding school level, we examined the differences between lower secondary schools and upper secondary schools. Once again, MANOVA 
was employed to inspect these differences (see Table 5$)(\Lambda=0.96 ; F=6.10 ; p$ $<.001$; partial $\eta^{2}=0.04$ ). We used pairwise comparisons with a Bonferroni adjustment for multiple comparisons (mean differences were significant at the .05 level). Students from lower secondary schools reported higher Support $(p<.01)$, Constructive use of time $(p<.001)$, Commitment to learning $(p<.05)$, Social competencies $(p<.05)$ and a Positive identity $(p<.01)$. There were no differences in Empowerment, Boundaries and expectations, and Positive values across school levels. Concerning the $5 \mathrm{Cs}$, students from lower secondary schools reported higher Competence $(p<.001)$ and a higher Connection $(p<.01)$. There were no school differences in Confidence, Character and Caring.

\section{Discussion}

PYD perceives youth as engaged, flourishing individuals who can find support in their environment. The first aim of the present paper was to examine this perspective in Slovenia with a focus on the psychometric evaluation of two PYD-related measures: DA and 5 Cs. Our second goal was to recognise the differences in gender and school level with a view to suggesting suitable interventions for each group observed.

Based on earlier research in the European context, we hypothesised the data would indicate a good fit for both questionnaires. After including some adjustments, an adequate fit for 8 first-order constructs of DA was established, although some target and non-target loadings were not acceptable since their loadings were poor. To our knowledge, just a few studies (i.e. Adams et al., 2018; Syvertsen et al., 2019; Wiium et al., 2019; Wiium et al., 2021) examined the measurement properties of the Developmental Assets Profile. Among these studies, only one study (Syvertsen et al., 2019) examined the psychometric properties in detail, which led to changing the questionnaire such that some items were removed or moved to another asset category. It must be noted that this study solely examined the CFA of each asset with some changes included, not the factor structure of the whole instrument. The factor loadings were comparable to those in our study despite the changes, except for Boundaries and expectations, Commitment to learning (which the authors named Academic achievement), Social competencies, and Positive values. Syvertsen and colleagues (2019) omitted Constructive use of time from CFA because it represents extracurricular activity participation and is not a psychological construct. 
The reason for the lower factor loadings in our study may lie in the breadth of the DA constructs, for instance, support from neighbours is included under Support and is mixed with Support from parents, family and school. Support from neighbours in Slovenia may be perceived differently than in the USA, especially in larger cities where most young people do not know their neighbours. We suggest that in the future general support be divided into sub-categories that include family support and support from the community. Further, among other external assets, Boundaries and expectations and Constructive use of time were the most problematic constructs and should therefore be observed with extra care or differentially included in future studies. Boundaries and expectations refer to two different important things: to various agents who serve as role models or care providers (i.e. friends, teachers, neighbours) and established rules on various occasions (i.e. at home, in the school). We believe these items should be divided into two different categories of boundaries and expectations, and not considered as one factor. In addition, Constructive use of time seems to be questionable, as reported in other studies as well (Wiium et al., 2019) since items measuring several extracurricular activities, spending time with friends and parents are combined in this construct. We suggest that in the future these items be considered separately as they refer to specific activities and not to a psychological construct.

Among internal assets, the items Social competencies and Positive values did not meet the desired criteria, indicating these two constructs should be examined with particular care. As for Positive values, the items can be divided into three different categories: helping others in society or the community, being responsible for oneself, and showing respect for other people. Including several positive values in a single construct seriously affected the factor loadings and we therefore suggest that the three mentioned dimensions be studied separately in the future. Moreover, Social competencies also included different values and competencies. Especially problematic are three items that refer to avoiding bad habits or the bad influence of other people and making good decisions. These items may be included in a sub-category of Positive values that indicates responsibility for oneself. Further, other items of Social competencies comprised accepting other people, being sensitive to their needs and feelings, expressing emotions appropriately, and solving conflicts with others without causing harm. All of these items could be included in a single category - Social competencies. 
For the $5 \mathrm{Cs}$, an adequate model fit for 5 first-order constructs was achieved, indicating that this questionnaire is suitable for use in the Slovenian context, even though our hypothesis that the bifactor model would be the best solution was not confirmed. The 5 first-order factor solution has already been confirmed in the European context as well (Conway et al., 2015). Factor loadings in the present study were comparable to those in the original study or even higher (Geldhof et al., 2014b). Still, two items of Character seemed problematic as they had lower factor loadings (i.e. "I hardly ever do things I know I shouldn't do" and "I usually act in the way I am supposed to"). They refer to conduct behaviour and not to the social conscience, personal values or diversity values like other Character items. Both items also weakly indicated Character in the original study (Geldhof et al., 2014b). This indicates that the construct of Character should be probed into in future studies.

At least partial scalar invariance was achieved for DA and the $5 \mathrm{Cs}$ for gender and school level. This allowed us to compare both PYD constructs across gender and school level since it showed that any possible statistical group differences were not a consequence of differences in scale properties reflected by gender or school level. In general, the results reveal that students differ more by gender than by school level. As for DA, male students reported having higher Support, Empowerment and a Positive identity while female students had higher Commitment to learning, Positive values and Social competencies. No differences were displayed for Boundaries and expectations and Constructive use of time. The results are not completely in line with our hypothesis or previous studies (Gomez-Baya et al., 2021) since males in Slovenia reported having greater Support and Empowerment. Moreover, in other studies (e.g. Rueger et al., 2010) female students were more likely to report support from teachers, close friends, classmates and school personnel compared to males, although they did not differ in support from their parents. As for the school level, students from lower secondary schools reported higher Support, Constructive use of time, Commitment to learning, Social competencies, and Positive identity than upper secondary students. This is consistent with our hypothesis and previous studies (Soares et al., 2019), indicating that lower secondary students have at least higher scores on some of the DA than upper secondary students. It is important to note that the data collection was carried out at a time of the COVID-19 pandemic when schools were closed. Especially students from the first grade of upper secondary schools were worse off 
than students in the other grades since they had only been at school for 1 month and were hence unable to establish supportive relationships with their classmates, teachers or participate in a new extracurricular activity.

Male and female students differed in all the ${ }_{5} \mathrm{Cs}$ because male students reported higher Competence, Confidence and Connection while female students scored higher for Character and Caring. These findings are partly consistent with previous results as most existing studies (Årdal et al., 2018; Gomez-Baya et al., 2019) reported that female students scored higher for Connection than male students. Regarding Caring, several studies showed that females have greater empathy than males (Van der Graaff et al., 2014) and that females score higher for character strengths than male students (Ruch et al., 2014). Like school-level differences in DA, differences among lower secondary students and upper secondary students were only revealed in Competence and Connection. Lower secondary students scored higher for Competence and Connection. Other studies (Conway et al., 2015) showed that younger adolescents reported higher Caring, Character and Connection, which means our findings are partly consistent with previous findings. As the findings are comparable to Support and Commitment to learning from DA, it is once again important to note that upper secondary students perceived less Support and Connection. This suggests that they might be overlooked by their peers due to not seeing (or even not being acquainted with) their classmates or their teachers were not paying enough attention to them or maybe they did not have a good relationship with their family or were unable to look for support in their community due to the COVID-19 restrictions. Further, additional research is needed to understand particular differences in Competence, Connection, Commitment to learning, Social competencies and Positive identity to recognise the possible effect of the COVID-19 restrictions.

Overall, Slovenian adolescents reported high DA and the ${ }_{5} \mathrm{Cs}$ regardless of gender and school type since most of the constructs of DA score higher than 3 on a scale of $1-4$, indicating they mostly stated that they experience all assets often. The only exception is Constructive use of time where we must stress that it was almost impossible to be involved in extracurricular activities or to spend time with one's friends because of the COVID-19 restrictions. In addition, almost all scores for the ${ }_{5} \mathrm{Cs}$ were higher than 3.5 on a scale of $1-5$ (except for Competence). These findings indicate that most young Slovenians are on a good and stable path towards their future despite school transitions, the pandemic, or other unpleasant events in their life. 


\section{Strengths and Limitations}

Our study relied a large sample of Slovenian adolescents from various lower or upper secondary schools, which enabled us to carefully examine PYD constructs transferred to the Slovenian context. On the other hand, our study has some limitations. It merely only involved DA and the ${ }_{5} \mathrm{Cs}$, therefore only structural validity was examined. Further, just one wave of the research project was included in the analysis, hence we were unable to focus on the longitudinal pathways of PYD constructs. Some constructs (i.e. Boundaries and expectations, Constructive use of time, Social competencies) should be examined with extra care due to their low reliability or factor loadings.

\section{Implications for future research and practice}

Based on our limitations, we suggest that additional variables (e.g. prosocial behaviour, risky behaviour, anxiety) be included in future analysis to ensure the convergent validity of both instruments. In addition, the revised version of the Developmental Assets Profile (Syvertsen et al., 2019) could be tested in the Slovenian context or the short 13-item version of the Developmental Assets Profile designed for emergencies could be applied (Scales et al., 2015). Since we did not concentrate on the connection between DA and the ${ }_{5} \mathrm{Cs}$, future studies should consider this relationship as well. Future studies should also apply person-centred methods to compare different profiles of PYD constructs and examine differences among them.

Finally, one aim of this study was to examine gender and school-level differences to enable us to prepare efficient and tailored prevention or intervention programmes. In particular, the findings reveal gender differences and thus some gender-specific prevention or intervention programmes should be applied. Since Benson et al. (2011) suggested that assets can be used to foster PYD outcomes (e.g. the ${ }_{5} \mathrm{Cs}$ ) and reduce risk behaviours, we will combine DA and the ${ }_{5} \mathrm{Cs}$ in order to suggest effective interventions. Males reported higher Support and Connection, which might indicate that family, peer or teacher support is needed for females. Higher peer and teacher support can be achieved through social games in the case of peers and additional time for personal communication with the teachers. Moreover, females scored high for Character but low for Empowerment, which may indicate they need extra opportunities to help others as can be gained by tutoring others, several voluntary practices and so on. Further, a Positive identity and Confidence may go hand in hand for females too, 
thereby making it important to ensure enough opportunities to boost their self-perceptions and good feelings about their future. Another ambiguous finding was that females scored higher for Commitment to learning and Social competencies, but lower for Competence. The reason for this might lie in athletic competence, which is included in Competence, indicating that females should be encouraged to find a sport they enjoy. Males reported lower Positive values and Character, which suggests they should be included in several activities that allow them to boost their character strengths (i.e. to identify their signature strengths, exercise their strengths). Males should also be included in some form of social and emotional learning programme to increase their Social competencies and foster empathy.

Since there were only minor differences across DA and the 5 Cs with respect to school level, suggesting that lower secondary students are slightly better off than upper secondary students, the latter should be involved in a comprehensive intervention that includes the whole classroom. Especially first-grade students in upper secondary schools should be properly welcomed in their new school and be allowed to spend some quality and bonding time with their classmates and their teachers without focusing on learning. When positive bonds are established among them, they should become more satisfied with themselves (i.e. a higher Positive identity) and connected to their peers, schoolmates and teachers.

\section{Conclusions}

The present study aimed to consider the psychometric properties of two PYD-related questionnaires in the Slovenian context and examine gender and school-level differences in developmental assets and the ${ }_{5} \mathrm{Cs}$. The results show that both PYD-related questionnaires can be used in the Slovenian context, although several recommendations are provided for the Developmental Assets Profile due to the lower factor loadings for certain constructs. At least partial scalar invariance was established for gender and school level, indicating that the differences between them were not a consequence of the measures. Male and female students differed in several developmental assets (i.e. Support, Empowerment, Positive identity, Commitment to learning, Positive values, Social competencies) and all ${ }_{5}$ Cs. Fewer differences were examined between lower and upper secondary school students as they differed in some developmental assets (i.e. Support, Constructive use of time, Commitment to learning, Social competencies, and Positive identity) and only 2 of the ${ }_{5} \mathrm{Cs}$ (i.e. Competence and 
Connection). These differences indicate that youth may benefit from targeted interventions that allow them to establish nurturing relationships and to stay on a good and stable path towards their future.

\section{Acknowledgments}

The Slovenian Research Agency supported this article as part of the project Positive Youth Development in Slovenia: Developmental Pathways in the Context of Migration (PYD-SI Model) [J5-1781].

\section{References}

Adams, B. G., Wiium, N., \& Abubakar, A. (2018). Developmental assets and academic performance of adolescents in Ghana, Kenya, and South Africa. Child \& Youth Care Forum, 48, 207-222. https://doi.org/10.1007/ S10566-018-9480-Z

Årdal, E., Holsen, I., Diseth, Å., \& Larsen, T. (2018). The five cs of positive youth development in a school context; gender and mediator effects. School Psychology International, 39(1), 3-21. https://doi. org/10.1177/0143034317734416

Beck, M., \& Wiium, N. (2019). Promoting academic achievement within a positive youth development framework. Norsk Epidemiologi, 28(1-2), 79-87. https://doi.org/10.5324/nje.v28i1-2.3054

Benson, P. L. (2003). Developmental Assets and Asset-Building Community: Conceptual and Empirical Foundations. In: Lerner R.M. \& Benson P.L. (Eds.) Developmental Assets and Asset-Building Communities. The Search Institute Series on Developmentally Attentive Community and Society, vol 1. (pp. 19-43). Springer. https://doi.org/10.1007/978-1-4615-0091-9_2

Benson, P. L., Scales, P. C., \& Syvertsen, A. K. (2011). The contribution of the developmental assets framework to positive youth development theory and practice. In R. M. Lerner, J. V. Lerner, \& J. B. Benson (Eds.), Advances in Child Development and Behavior (pp. 197-230). Elsevier. https://doi. org/10.1016/B978-0-12-386492-5.00008-7

Bowers, E. P., Li, Y., Kiely, M. K., Brittian, A., Lerner, J. V., \& Lerner, R. M. (2010). The five Cs model of positive youth development: A longitudinal analysis of confirmatory factor structure and measurement invariance. Journal of Youth and Adolescence, 39(7), 720-735. https://doi.org/10.1007/ s10964-010-9530-9 
Cheung, G. W., \& Rensvold, R. B. (2002). Evaluating goodness-of-fit indexes for testing measurement invariance. Struct. Equat. Model. 9, 233-255. https://doi.org/10.1207/S15328007SEMo902_5

Conway, R. J., Heary, C., \& Hogan, M. J. (2015). An evaluation of the measurement properties of the five Cs model of Positive Youth Development. Frontiers in Psychology, 6(DEC), 1-13. https://doi.org/10.3389/fpsyg.2015.01941

Geldhof, G. J., Bowers, E. P., Boyd, M. J., Mueller, M. K., Napolitano, C. M., Schmid, K. L., Lerner, J. V., \& Lerner, R. M. (2014a). Creation of short and very short measures of the five Cs of positive youth development. Journal of Research on Adolescence, 24(1), 163-176. https://doi.org/10.1111/ jora.12039

Geldhof, G. J., Bowers, E. P., Mueller, K. M., Napolitano, C. M., Schmid Callina, K., \& Lerner, R. M. (2014b). Longitudinal Analysis of a Very Short Measure of Positive Youth Development. Journal of Youth and Adolescence, 43(6), 933-949. https://doi.org/10.1007/s10964-014-0093-Z

Gomez-Baya, D., Reis, M., \& Gaspar de Matos, M. (2019). Positive youth development, thriving and social engagement: An analysis of gender differences in Spanish youth. Scandinavian Journal of Psychology, 6o(6), 559-568. https://doi.org/10.1111/sjop.12577

Gomez-Baya, D., Santos, T., \& Gaspar de Matos, M. (2021). Developmental assets and positive youth development: an examination of gender differences in Spain. Applied Developmental Science, o(o), 1-23. https://doi.org/10.1 o8o/10888691.2021.1906676

Hair, J. F., Jr., Anderson, R. E., Tatham, R. L., \& Black, W. C. (1998). Multivariate data analysis. Fifth Edition. Upper Saddle River, NJ: Prentice-Hall International.

Heck, K. E., \& Subramaniam, A. (2009). Youth development frameworks. [Monograph]. Davis, CA: 4-H Center for Youth Development, University of California.

Hu, L. T., \& Bentler, P. M. (1999). Cutoff criteria for fit indexes in covariance structure analysis: Conventional criteria versus new alternatives. Structural Equation Modeling, 6(1), 1-55. https://doi.org/10.1080/10705519909540118

Jeriček Klanšček H., Roškar S., Vinko M., Konec Juričič N., Hočevar Grom A., Bajt, M., Čuš, A., Furman, L., Zager Kocjan, G., Hafner, A., Medved, T., Floyd Bračič, M. \& Poldrugovac, M. (2018). Duševno Zdravje Otrok in Mladostnikov v Sloveniji. Ljubljana: Nacionalni inštitut za javno zdravje. 
Kozina, A., Wiium, N., Gonzalez, J. M., \& Dimitrova, R. (2019). Positive Youth Development and academic achievement in Slovenia. Child and Youth Care Forum, 48(2), 223-240. https://doi.org/10.1007/s10566-018-9457-y

Leffert, N., Benson, P. L., Scales, P. C., Sharma, A. R., Drake, D. R., \& Blyth, D. A. (1998). Developmental assets: Measurement and prediction of risk behaviors among adolescents. Applied Developmental Science, 2(4), 209230. https://doi.org/10.1207/s1532480xadso204_4

Lerner, R. M., Lerner, J. V., Almerigi, J. B., Theokas, C., Phelps, E., Gestsdottir, S., Naudeau, S., Jelicic, H., Alberts, A., Ma, L., Smith, L. M., Bobek, D. L., Richman-Raphael, D., Simpson, I., Christiansen, E. D. D., \& Von Eye, A. (2005). Positive youth development, participation in community youth development programs, and community contributions of fifthgrade adolescents: Findings from the first wave of the 4-H study of positive youth development. Journal of Early Adolescence, 25(1), 17-71. https:// doi.org/10.1177/0272431604272461

Lerner, R. M., Tirrell, J. M., Dowling, E. M., Geldhof, G. J., Gestsdóttir, S., Lerner, J. V., King, P. E., Williams, K., Iraheta, G., \& Sim, A. T. R. (2019). The End of the Beginning: Evidence and Absences Studying Positive Youth Development in a Global Context. Adolescent Research Review, 4(1), 1-14. https://doi.org/10.1007/s40894-018-0093-4

Morin, A. J. S., Katrin Arens, A., \& Marsh, H. W. (2015). A bifactor exploratory structural equation modeling framework for the identification of distinct sources of construct-relevant psychometric multidimensionality. Structural Equation Modeling, 23(1), 116-139. https://doi.org/10.1080/10 705511.2014.961800

Muthén, L. K., \& Muthén, B. O. (1998-2021). Mplus User's Guide. Eighth Edition. Muthén \& Muthén.

Overton, W. F. (2015). Processes, relations, and relational-developmental-systems. In R. M. Lerner (Ed.), Handbook of Child Psychology and Developmental Science, (pp. 1-54). Wiley.

Phelps, E., Zimmerman, S., Warren, A. E. A., Jeličić, H., von Eye, A., \& Lerner, R. M. (2009). The structure and developmental course of Positive Youth Development (PYD) in early adolescence: Implications for theory and practice. Journal of Applied Developmental Psychology, 30(5), 571-584. https://doi.org/10.1016/j.appdev.2009.06.003

Pivec, T., Kozina, A., Wiium, N., \& Uka, F. (2020). Are the 5 Cs of Positive Youth Development related to risky behaviours: Analysis Across Countries. In C. Pracana \& M. Wang (Eds.), Psychology Applications \& Developments 
VI (pp. 194-203). InScience Press. https://doi.org/10.36315/2020inpacto46. pdf

Roškar, S., Sedlar, N., Furman, L., Roškar, M., \& Podlesek, A. (2020). Association of selected area-level indicators with suicide mortality in Slovenian municipalities. Crisis: The Journal of Crisis Intervention and Suicide Prevention. Advance online publication. https://doi.org/10.1027/0227-5910/aooo742

Roth, J. L., \& Brooks-Gunn, J. (2016). Evaluating youth development programs: Progress and promise. Physiology \& Behavior, 2o(3), 188-202. https://doi. org/10.1016/j.physbeh.2017.03.040

Ruch, W., Weber, M., Park, N., \& Peterson, C. (2014). Character strengths in children and adolescents. European Journal of Psychological Assessment, 3o(1), 57-64. https://doi.org/10.1027/1015-5759/aooo169

Rueger, S. Y., Malecki, C. K., \& Demaray, M. K. (2010). Relationship between multiple sources of perceived social support and psychological and academic adjustment in early adolescence: Comparisons across gender. Journal of Youth and Adolescence, 39(1), 47-61. https://doi.org/10.1007/ s10964-008-9368-6

Scales, P. C. (2011). Youth developmental assets in global perspective: Results from international adaptations of the developmental assets profile. Child Indicators Research , 4(4), 619-645. https://doi.org/10.1007/s12187-011-9112-8

Scales, P. C., Roehlkepartain, E. C., Wallace, T., Inselman, A., Stephenson, P., \& Rodriguez, M. (2015). Brief report: Assessing youth well-being in global emergency settings: Early results from the Emergency Developmental Assets Profile. Journal of Adolescence, 45, 98-102. https://doi.org/10.1016/j. adolescence.2015.09.002

Search Institute. (2005). Developmental assets profile: User manual. Search Institute.

Soares, A. S., Pais-Ribeiro, J. L., \& Silva, I. (2019). Developmental assets predictors of life satisfaction in adolescents. Frontiers in Psychology, 10, 1-11. https://doi.org/10.3389/fpsyg.2019.00236

SURS. (2021). Education. Retrieved from: https://pxweb.stat.si/SiStat/sl/ Podrocja/Index/192/izobrazevanje (13. 8. 2021)

Syvertsen, A. K., Scales, P. C., \& Toomey, R. B. (2019). Developmental Assets framework revisited: Confirmatory analysis and invariance testing to create a new generation of assets measures for applied research. Applied Developmental Science, 1-16. https://doi.org/10.1080/10888691.2019.1613155

Tabachnick, B. G., \& Fidell, L. S. (2006). Using multivariate statistics. Fifth Edition. Allyn and Bacon. 
Taštanoska, T. (Ed.). (2017). The education system in the Republic of Slovenia 2016/2017. Ministry of Education, Science and Sport of the Republic of Slovenia.

Tirrell, J. M., Geldhof, G. J., King, P. E., Dowling, E. M., Sim, A. T. R., Williams, K., Iraheta, G., Lerner, J. V., \& Lerner, R. M. (2019). Measuring spirituality, hope, and thriving among Salvadoran youth: Initial findings from the compassion international study of positive youth development. Child \& Youth Care Forum, 48(2), 241-268. https://doi.org/10.1007/ s10566-018-9454-1

Van der Graaff, J., Branje, S., De Wied, M., Hawk, S., Van Lier, P., \& Meeus, W. (2014). Perspective taking and empathic concern in adolescence: Gender differences in developmental changes. Developmental Psychology, 50(3), 881-888. https://doi.org/10.1037/aoo34325

Wiium, N., Beck, M., \& Ferrer-Wreder, L. (2021). The importance of developmental assets to mental health in Norwegian youth. Frontiers in Psychology. 12:687537. https://doi.org/10.3389/fpsyg.2021.687537

Wiium, N., Dost-Gözkan, A., \& Kosic, M. (2019). Developmental Assets Among Young People in Three European Contexts: Italy, Norway and Turkey. Child and Youth Care Forum, 48(2), 187-206. https://doi.org/10.1007/ s10566-018-9446-1 